\title{
Blocking Antibody
}

National Cancer Institute

\section{Source}

National Cancer Institute. Blocking Antibody. NCI Thesaurus. Code C17898.

An antibody that binds to endogenous or exogenous compounds and inhibits the biological activity of that compound. 